\title{
Intermetallic Compounds Formed during the Reflow of In-49Sn Solder Ball-Grid Array Packages
}

\author{
T.H. CHUANG, ${ }^{1,2}$ S.Y. CHANG, ${ }^{1}$ L.C. TSAO, ${ }^{1}$ W.P. WENG,${ }^{1}$ and H.M. WU ${ }^{1}$ \\ 1.-Institute of Materials Science and Engineering, National Taiwan University, Taipei 106, Taiwan. \\ 2._E-mail: tunghan@ccms.ntu.edu.tw
}

\begin{abstract}
The intermetallic compounds formed at the interfaces between In-49Sn solder balls and $\mathrm{Au} / \mathrm{Ni} / \mathrm{Cu}$ pads during the reflow of In-49Sn solder, ball-grid array (BGA) packages are investigated. Various temperature profiles with peak temperatures ranging from $140^{\circ} \mathrm{C}$ to $220^{\circ} \mathrm{C}$ and melting times ranging from $45 \mathrm{sec}$ to $170 \mathrm{sec}$ are plotted for the reflow processes. At peak temperatures below $170^{\circ} \mathrm{C}$, a continuous double layer of intermetallics can be observed, showing a composition of $\mathrm{Au}(\mathrm{In}, \mathrm{Ni})_{2} / \mathrm{Au}(\mathrm{In}, \mathrm{Ni})$. Through selective etching of the In-49Sn solders, the intermetallic layer is made up of irregular coarse grains. In contrast, a number of cubic-shaped $\mathrm{AuIn}_{2}$ intermetallic compounds appear at the interfaces and migrate toward the upper domes of In-49Sn solder balls after reflow at peak temperatures above $200^{\circ} \mathrm{C}$ for longer melting times. The upward floating of the $\mathrm{AuIn}_{2}$ cubes can be explained by a thermomigration effect caused by the temperature gradient present in the liquid solder ball. The intermetallic compounds formed under various reflow conditions in this study exhibit different types of morphology, yet the ball shear strengths of the solder joints in the In-49Sn BGA packages remain unaffected.
\end{abstract}

Key words: In-49Sn solder balls, BGA, $\mathrm{Au} / \mathrm{Ni} / \mathrm{Cu}$ pads, intermetallic

\section{INTRODUCTION}

Gold thin films are widely used in electronic packaging to prevent oxidation and promote the wettability of $\mathrm{Cu}$ pads or Ni reaction layers. However, Au can be easily dissolved in Sn-based solders to form $\mathrm{AuSn}_{4}$ precipitates, which can lead to the embrittlement of solder joints. ${ }^{1}$ It has been reported that such a gold embrittlement failure in advanced packaging can be inhibited in In-Sn solders because of the lower solubility of $\mathrm{Au}$ in In-Sn. ${ }^{2}$ Shohji et al. studied the solid/solid reaction between $\mathrm{Au}$ and In-49Sn solder and showed that an $\mathrm{AuIn}_{2}$ layer and a $\gamma$-phase layer were formed at the $\mathrm{Au} / \mathrm{In}-49 \mathrm{Sn}$ interface. ${ }^{3}$ The activation energy for the formation of $\mathrm{AuIn}_{2}$ was $42.8 \mathrm{~kJ} / \mathrm{mol}$, equivalent to the activation energy for the diffusion of $\mathrm{Au}$ in $\mathrm{AuIn}_{2}$. Such a continuous interfacial $\mathrm{AuIn}_{2}$ layer was believed to act as a barrier to the dissolution of $\mathrm{Au}$ in In-based solders. ${ }^{4}$

The $\mathrm{Au} / \mathrm{Ni} / \mathrm{Cu}$ is a popular pad structure of ballgrid array (BGA) packages. Owing to the merits of greater ductility, longer fatigue life, and lower melting point than the more traditional $\mathrm{Pb}-\mathrm{Sn}$ solders,${ }^{5-9}$ the eutectic In-49Sn alloy is considered a

(Received May 30, 2002; accepted July 27, 2002)
$\mathrm{Pb}$-free solder-ball material for BGA packages. This study is concerned with the characterization of intermetallic compounds formed at the interfaces between liquid In-49Sn solders and $\mathrm{Au} / \mathrm{Ni} / \mathrm{Cu}$ pads during the reflow of BGA packages under various conditions.

\section{EXPERIMENTAL}

The geometry of BGA specimens used in this study is shown in Fig. 1. A silicon die of size of $4.5 \mathrm{~mm} \times$ $4.5 \mathrm{~mm} \times 0.25 \mathrm{~mm}$ was attached to a bismaleimide triazine (BT) resin substrate and encapsulated in a molding compound. Each package was fitted with 49 $\mathrm{Cu}$ pads electroplated with 5 - $\mu \mathrm{m}$-thick $\mathrm{Ni}$ and 0.5 $\mu \mathrm{m}$-thick Au. The In-49 (wt.\%) Sn solder balls of 0.4 $\mathrm{mm}$ in diameter were dipped in rosin, mildly activated flux, placed on the $\mathrm{Au} / \mathrm{Ni} / \mathrm{Cu}$ pads, and then reflowed in an infrared furnace. The reflow furnace had five heating zones with a typical temperature profile, as shown in Fig. 2. The reflow process was performed at various peak temperatures $\left(\mathrm{T}_{\text {max. }}\right)$ ranging from $140^{\circ} \mathrm{C}$ to $220^{\circ} \mathrm{C}$ for various melting time periods $(\Delta \mathrm{t})$. As the temperature rose above the eutectic point of the In-49Sn solder $\left(\mathrm{Te}=120^{\circ} \mathrm{C}\right)$, liquid/solid reactions took place at the interfaces between $\mathrm{In}-49 \mathrm{Sn}$ solder balls and $\mathrm{Au} / \mathrm{Ni} / \mathrm{Cu}$ pads. 


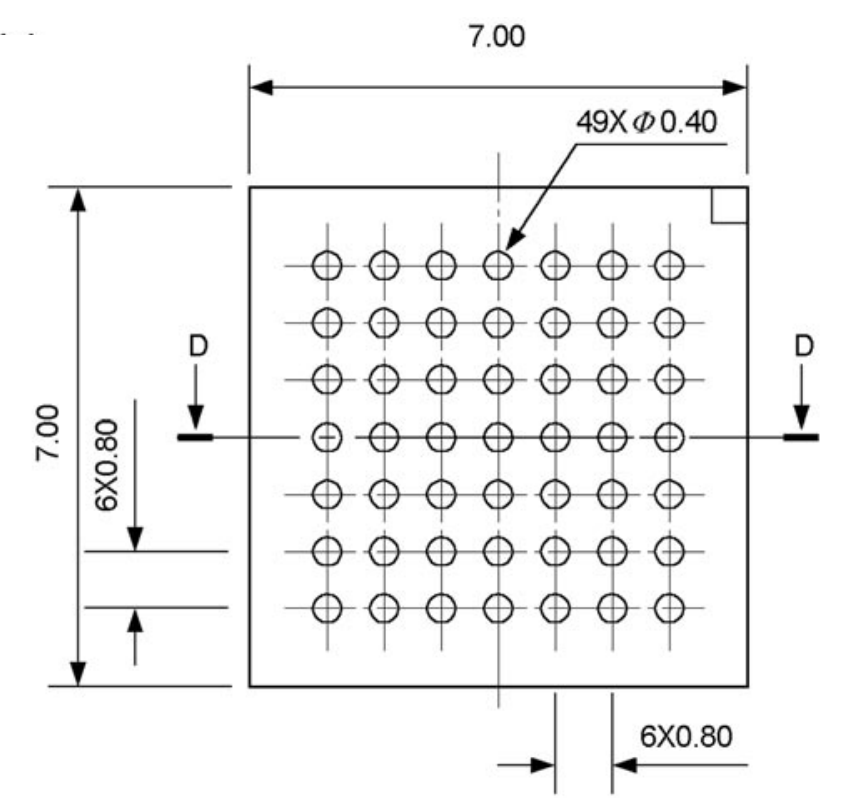

a

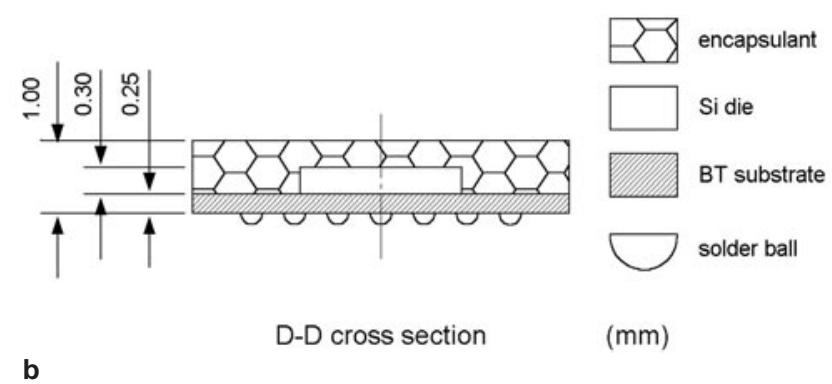

Fig. 1. Geometry of BGA specimens used in this study: (a) solder ball distribution and (b) package cross section.

After reflow, the specimens were cross sectioned through a row of solder balls, ground with 1,500-grit $\mathrm{SiC}$ paper, and polished with $0.3-\mu \mathrm{m} \mathrm{Al}_{2} \mathrm{O}_{3}$ powder. The intermetallic compounds formed during reflow were observed with a scanning electron microscope (SEM) and analyzed using an electron probe microanalyzer (EPMA). The three-dimensional morphology of the intermetallic compounds was also probed through the selectively etched specimens. For this purpose, an etching solution of $10-\mathrm{mL} \mathrm{HF}, 10-\mathrm{mL}$ $\mathrm{H}_{2} \mathrm{O}_{2}$, and $40-\mathrm{mL} \mathrm{H}_{2} \mathrm{O}$ was employed to dissolve the In-49Sn solder and retain the intermetallic compounds at the solder/pad interfaces.

The bonding strengths of In-49Sn solder balls on $\mathrm{Au} / \mathrm{Ni} / \mathrm{Cu}$ pads under various reflow conditions were measured via ball shear tests. The measurements were taken at a shear rate of $0.1 \mathrm{~mm} / \mathrm{sec}$ and a shear height of $80 \mu \mathrm{m}$ (about $1 / 4$ the reflowed ball height). The fractography of the solder joints after ball shear tests was examined in the SEM.

\section{RESULTS AND DISCUSSION}

Figure 3 shows the typical morphology of intermetallic compounds formed at the interfaces be-

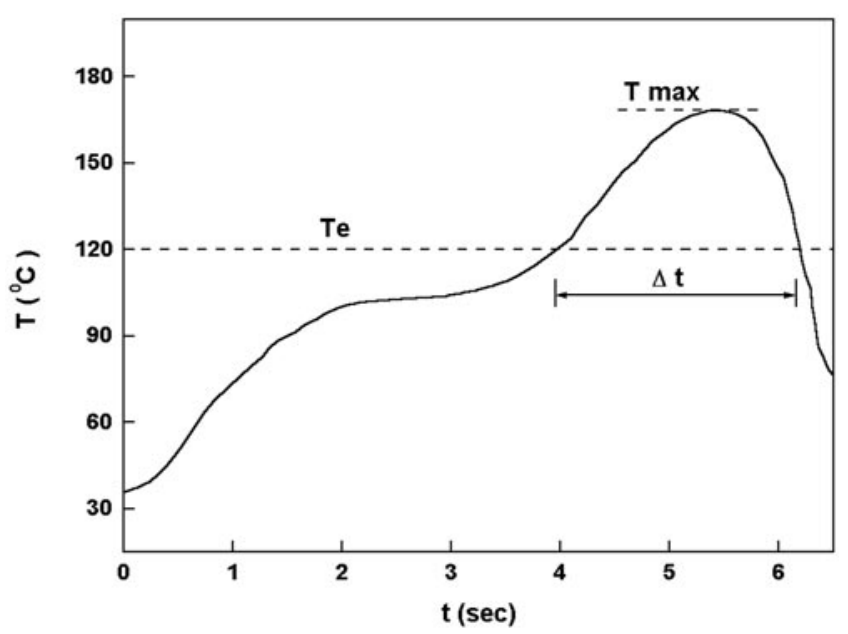

Fig. 2. Typical temperature profile for the reflow of In-49Sn solder BGA packages in this study ( $T_{\text {max. }}$ : peak temperature, $\Delta$ t: melting time period, and Te: eutectic point of In-49Sn).

tween In-49Sn solder balls and $\mathrm{Au} / \mathrm{Ni} / \mathrm{Cu}$ pads after reflow at the peak temperature of $170^{\circ} \mathrm{C}$ for various melting time periods. The intermetallic compounds appear in the form of a continuous double layer at this peak temperature even after a long melting time. The EPMA analyses show that the composition (at.\%) of the outer layer is $\mathrm{Au}: \mathrm{In}: \mathrm{Ni}=34.3: 60.6: 5.1$, corresponding to a $\mathrm{Au}(\mathrm{In}, \mathrm{Ni})_{2}$ phase. However, the inner layer of the intermetallic compounds achieves a composition of Au:In:Ni = 51.2:41.5:7.3, which corresponds to an $\mathrm{Au}(\mathrm{In}, \mathrm{Ni})$ phase.

As the peak temperature is increased to $220^{\circ} \mathrm{C}$, the intermetallic compounds are found to change from a continuous layer into a nearly square shape, as shown in Fig. 4. Figure 5 shows the morphological variation of the intermetallic compounds formed during reflow at different peak temperatures for the BGA In-49Sn solder. The continuous intermetallic layers remain intact below $170^{\circ} \mathrm{C}$, but at temperatures above $200^{\circ} \mathrm{C}$, the intermetallic compounds begin to transform into a cubic shape. The cubic-shaped intermetallics can keep growing with the increase of peak temperature and melting time to a size larger than $10 \mu \mathrm{m}$, as shown in Figs. 4 and 5. To highlight such an interesting observation of intermetallic changes in morphology for the BGA In-49Sn solder reflowed under various conditions, Fig. 6 offers a clearer picture of the continuous $\mathrm{Au}(\mathrm{In}, \mathrm{Ni})_{2} / \mathrm{Au}(\mathrm{In}, \mathrm{Ni})$ intermetallic double layer and the cubic-shaped $\mathrm{AuIn}_{2}$ intermetallics formed, respectively, at the peak temperatures of $170^{\circ} \mathrm{C}$ and $200^{\circ} \mathrm{C}$. The EPMA analyses indicate that the composition (at.\%) of these cubicshaped intermetallics is $\mathrm{Au}: \mathrm{In}=33.5: 66.5$, which matches the AuIn 2 phase. After the formation of the cubic $\mathrm{AuIn}_{2}$ intermetallics, the Au film disappears, while the liquid In-49Sn solder continues to react with the Ni layer.

With the In-49Sn solder selectively etched away from the BGA specimen reflowed at the peak temperature $170^{\circ} \mathrm{C}$ for a melting time of $70 \mathrm{sec}$, Fig. $7 \mathrm{a}$ demonstrates that the continuous interfacial inter- 

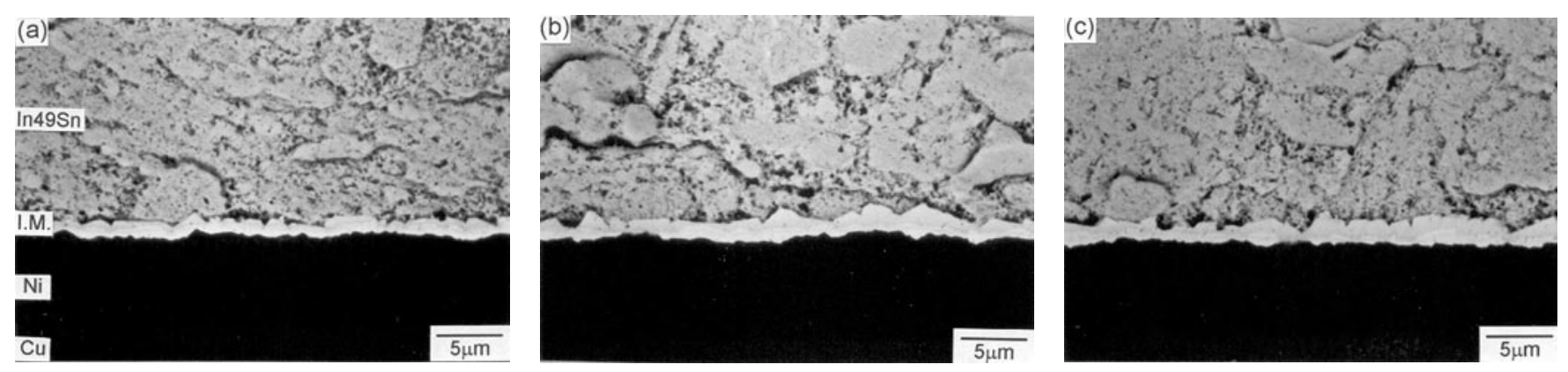

Fig. 3. Morphology of intermetallic compounds formed at the interfaces between In-49Sn solders and Au/Ni/u pads after reflow at $170^{\circ} \mathrm{C}$ for various melting time periods: (a) $60 \mathrm{sec}$, (b) $100 \mathrm{sec}$, (c) $120 \mathrm{sec}$.
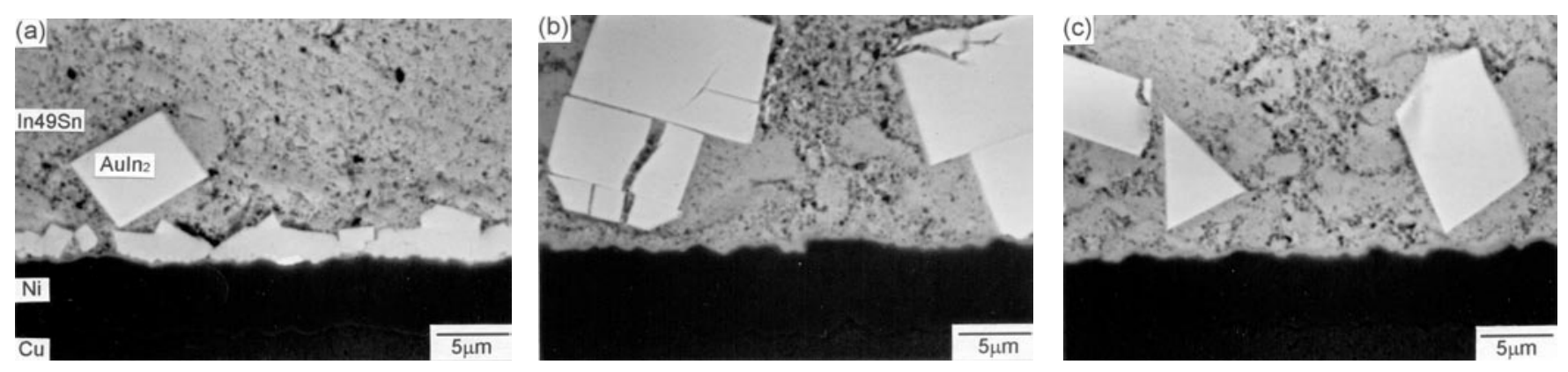

Fig. 4. Morphology of intermetallic compounds formed at the interfaces between In-49Sn solders and Au/Ni/Cu pads after reflow at $220^{\circ} \mathrm{C}$ for various melting time periods: (a) $105 \mathrm{sec}$, (b) $140 \mathrm{sec}$, and (c) $170 \mathrm{sec}$.
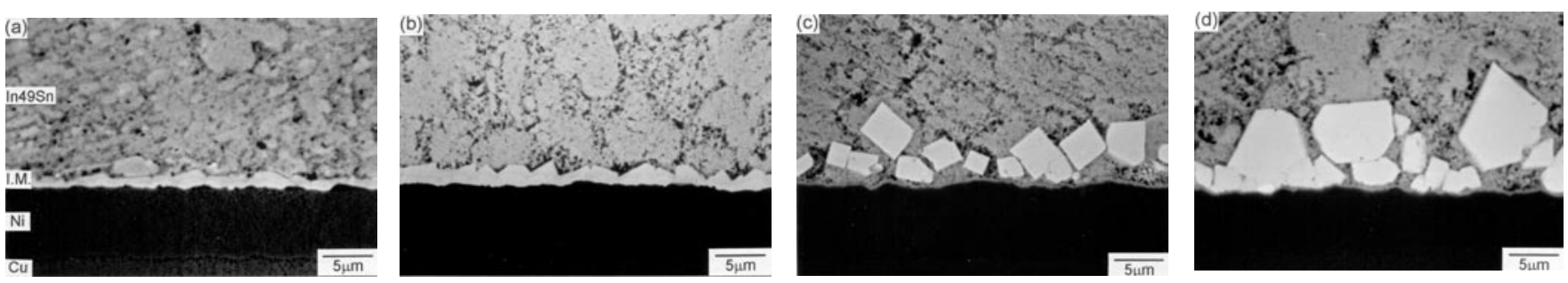

Fig. 5. Morphology of intermetallic compounds formed at the interfaces between In-49Sn solders and Au/Ni/Cu pads after reflow at various peak temperatures for various melting time periods: (a) $150^{\circ} \mathrm{C}, 125 \mathrm{sec}$; (b) $170^{\circ} \mathrm{C}, 140 \mathrm{sec}$; (c) $200^{\circ} \mathrm{C}, 160 \mathrm{sec}$; and (d) $220^{\circ} \mathrm{C}, 120 \mathrm{sec}$.

metallic layer from Fig. 3 is composed of irregular coarse grains with an average size of about $3 \mu \mathrm{m}$. Their typical chemical composition (at.\%) as analyzed at Location $\mathrm{A}$ is $\mathrm{Au}: \mathrm{In}: \mathrm{Ni}=75.4: 8.3: 16.3$, which corresponds to an ordered $\varepsilon^{\prime}$ phase. In Fig. 7a, a few regions in the coarse-grained matrix are covered with fine-grained clusters, which have a composition of $\mathrm{Au}: \mathrm{In}: \mathrm{Ni}=87.6: 10.4: 2.0$, corresponding to the $\alpha_{1}$ phase. With the melting time increased to $140 \mathrm{sec}$ at the peak temperature of $170^{\circ} \mathrm{C}$, it is found in the selectively etched specimen that those irregular coarse grains have grown further to an average size of about $6 \mu \mathrm{m}$. The composition as analyzed from Location $\mathrm{C}$ is $\mathrm{Au}: \mathrm{In}: \mathrm{Ni}=31.7: 60.1: 8.2$, corresponding to the $\mathrm{Au}(\mathrm{In}, \mathrm{Ni})_{2}$ phase similar to that of the outer intermetallic layer in Fig. 3. Accompanying the grain growth in the matrix, the fine-grained clusters in the $\alpha_{1}$ phase disappear, resulting in the exposure of a number of small areas beneath the $\mathrm{Au}(\mathrm{In}, \mathrm{Ni})_{2}$ intermetallic coarse grains, as shown in Location D. The composition of these areas is Ni:In:Sn = 75.1:17.1:7.8, corresponding to the $\mathrm{Ni}_{3}(\mathrm{In}, \mathrm{Sn})$ phase. Although
$\mathrm{Ni}_{3} \mathrm{In}$ and $\mathrm{Ni}_{3} \mathrm{Sn}$ are listed in the Ni-In and Ni-Sn phase diagrams, they have never been reported as the products of soldering reactions between In (or Sn, InSn) and Ni substrates. ${ }^{11-13}$ During the interfacial reactions between liquid $\mathrm{In}-49 \mathrm{Sn}$ solders and $\mathrm{Ni}$ substrates at temperatures ranging from $150^{\circ} \mathrm{C}$ to $300^{\circ} \mathrm{C}$, a $\mathrm{Ni}_{33} \mathrm{In}_{18.5} \mathrm{Sn}_{48.5}$ intermetallic compound was observed, rather than the $\mathrm{Ni}_{3}(\mathrm{In}, \mathrm{Sn})$ phase. ${ }^{13}$ The $\mathrm{Ni}_{3} \mathrm{Sn}$ intermetallic compound, was reported by Bader et al. in their study on the intermetallic formation during the interdiffusion between $\mathrm{Ni}$ and $\mathrm{Sn}$ thin films, respectively, of $4.1 \mu \mathrm{m}$ and $2.6 \mu \mathrm{m}$ in thickness. ${ }^{14}$ After heating at $400^{\circ} \mathrm{C}$ for $90 \mathrm{~h}$, the $\mathrm{Sn}$ film was exhausted, which spurred the reaction of the formerly created $\mathrm{Ni}_{3} \mathrm{Sn}_{2}$ phase with the remainder of the $\mathrm{Ni}$ film to form a columnar-grained $\mathrm{Ni}_{3} \mathrm{Sn}$ intermetallic. In the present study, the appearance of the $\mathrm{Ni}_{3}(\mathrm{In}, \mathrm{Sn})$ phase is believed to also result from insufficient In and Sn supply caused by the barrier effect of the $\mathrm{Au}(\mathrm{In}, \mathrm{Sn})_{2}$ layer wrought on the In-49Sn solder. The limited amount of In and Sn from the $\mathrm{Au}(\mathrm{In}, \mathrm{Sn})_{2}$ layer reacts with the thicker $\mathrm{Ni}$ 

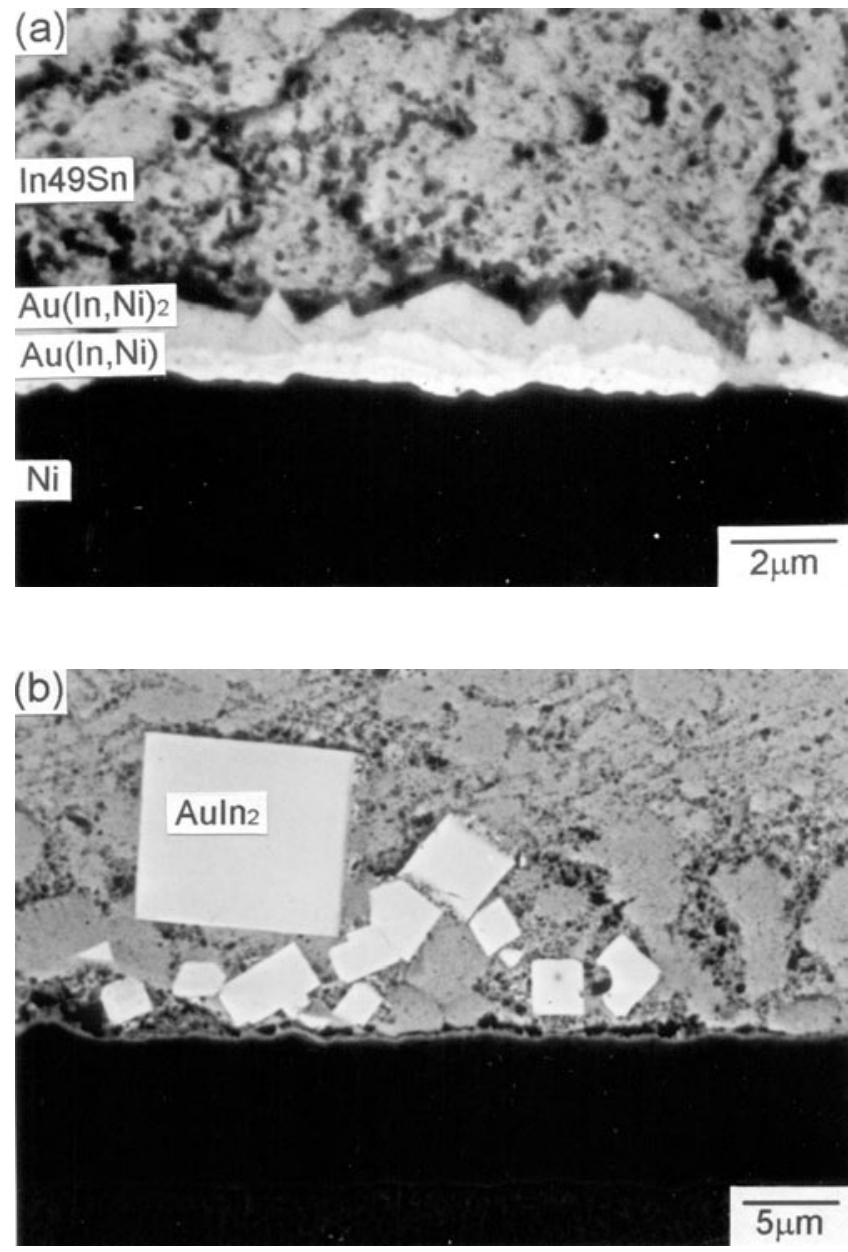

Fig. 6. Continuous double layer $\mathrm{Au}(\mathrm{In}, \mathrm{Ni})_{2} / \mathrm{Au}(\mathrm{In}, \mathrm{Sn})$ and cubic shape Auln $_{2}$ intermetallic compounds formed during the reflow of BGA in-49Sn solder at (a) $170^{\circ} \mathrm{C}$ for $140 \mathrm{sec}$ and (b) $200^{\circ} \mathrm{C}$ for $160 \mathrm{sec}$.

layer to form the Ni-rich $\mathrm{Ni}_{3}(\mathrm{In}, \mathrm{Sn})$ intermetallics, conducive also to the transformation of particle $\mathrm{Au}(\mathrm{In}, \mathrm{Sn})_{2}$ into $\mathrm{Au}(\mathrm{In}, \mathrm{Sn})$ adjacent to the $\mathrm{Ni}_{3}(\mathrm{In}, \mathrm{Sn})$ phase.

Figure $8 \mathrm{a}$ shows a selectively etched specimen whose three-dimensional morphology is given as evidence of the $\mathrm{AuIn}_{2}$ intermetallic compounds of cubic shape formed at peak temperatures above $200^{\circ} \mathrm{C}$. It has been reported that $\mathrm{AuIn}_{2}$ has a $\mathrm{CaF}_{2}(\mathrm{C} 1)$-type structure. ${ }^{10}$ The appearance of cubic-shaped $\mathrm{AuIn}_{2}$ intermetallic compounds (Fig. 8a) implies that the surface energy of their (100) planes is quite low. Figure $8 \mathrm{~b}$ is a magnified view of the matrix from Fig. 8a, which reveals a morphology of very fine grains. The EPMA analysis identifies the composition of the fine-grained matrix as Ni:Sn:In = 43.4:39.2:17.4, which corresponds to the $\mathrm{Ni}_{3}(\mathrm{In}, \mathrm{Sn})_{4}$ phase. The $\mathrm{Ni}_{3}(\mathrm{In}, \mathrm{Sn})_{4}$ intermetallic compound at the interface of the In-49Sn solder BGA package is consistent with the reaction product $\mathrm{Ni}_{3} \mathrm{Sn}_{4}$, which appeared during the soldering reactions between liquid $\mathrm{Sn}$ and Ni substrates, contrasting that in the literature to the formation of $\mathrm{Ni}_{33} \mathrm{In}_{18.5} \mathrm{Sn}_{48.5}$ intermetallic at the In- $49 \mathrm{Sn}_{(\mathrm{L})} / \mathrm{Ni}_{(\mathrm{S})}$ interface. ${ }^{13}$ The dis-
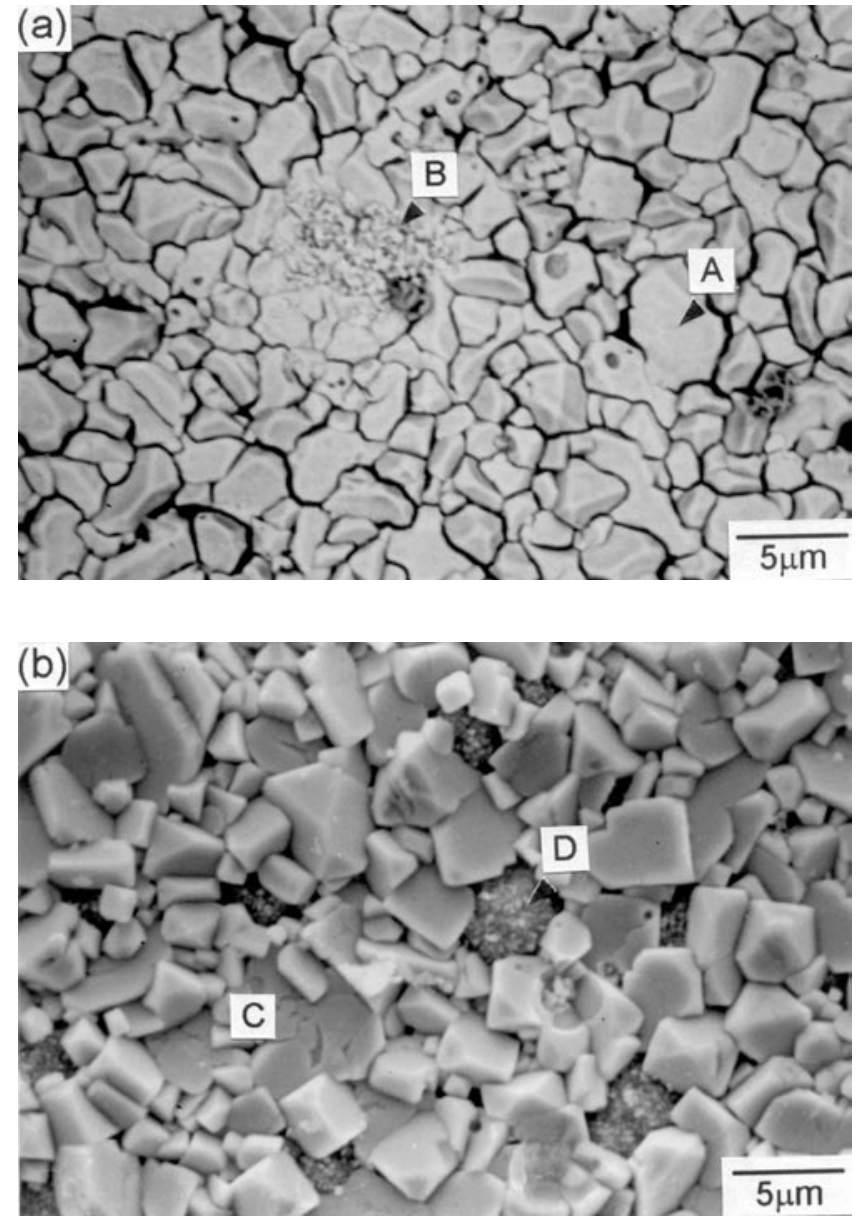

Fig. 7. Selective etching of the In-49Sn solders showing that irregular granular interfacial intermetallic compounds are formed in BGA specimens after reflow at $170^{\circ} \mathrm{C}$ for various melting time periods: (a) $70 \mathrm{sec}$ and (b) $140 \mathrm{sec}$.

crepancy can be attributed to the excessive consumption of In from the In-49Sn during its reaction with Au film, which results in an In-Sn alloy with high $\mathrm{Sn}$ content adjacent to the $\mathrm{Au} / \mathrm{Ni} / \mathrm{Cu}$ pads to react with the Ni layer.

Another interesting phenomenon can be observed from Fig. 9, i.e., the $\mathrm{AuIn}_{2}$ intermetallic cubes float toward the top of the In49-Sn solder ball. As the peak reflow temperature increases, more $\mathrm{AuIn}_{2}$ cubes migrate through the In-49Sn solder ball and settle on its upper dome. Because $\mathrm{AuIn}_{2}$ is specifically much denser than In-49Sn solder, it seems unreasonable that the heavier $\mathrm{AuIn}_{2}$ is able to float upward in liquid In-49Sn solder. An explanation is proposed based on the thermomigration theory: ${ }^{15,16}$ the upper dome of the solder ball is irradiated with infrared heat during reflow, which gives rise to a temperature gradient between the top and bottom of the solder ball. Because of this temperature gradient, the liquid In49Sn solder migrates downward, and the $\mathrm{AuIn}_{2}$ cubes are squeezed upward instead to settle on the upper side of the solder ball.

Fractography on all BGA specimens reflowed under various conditions shows ductile failure char- 

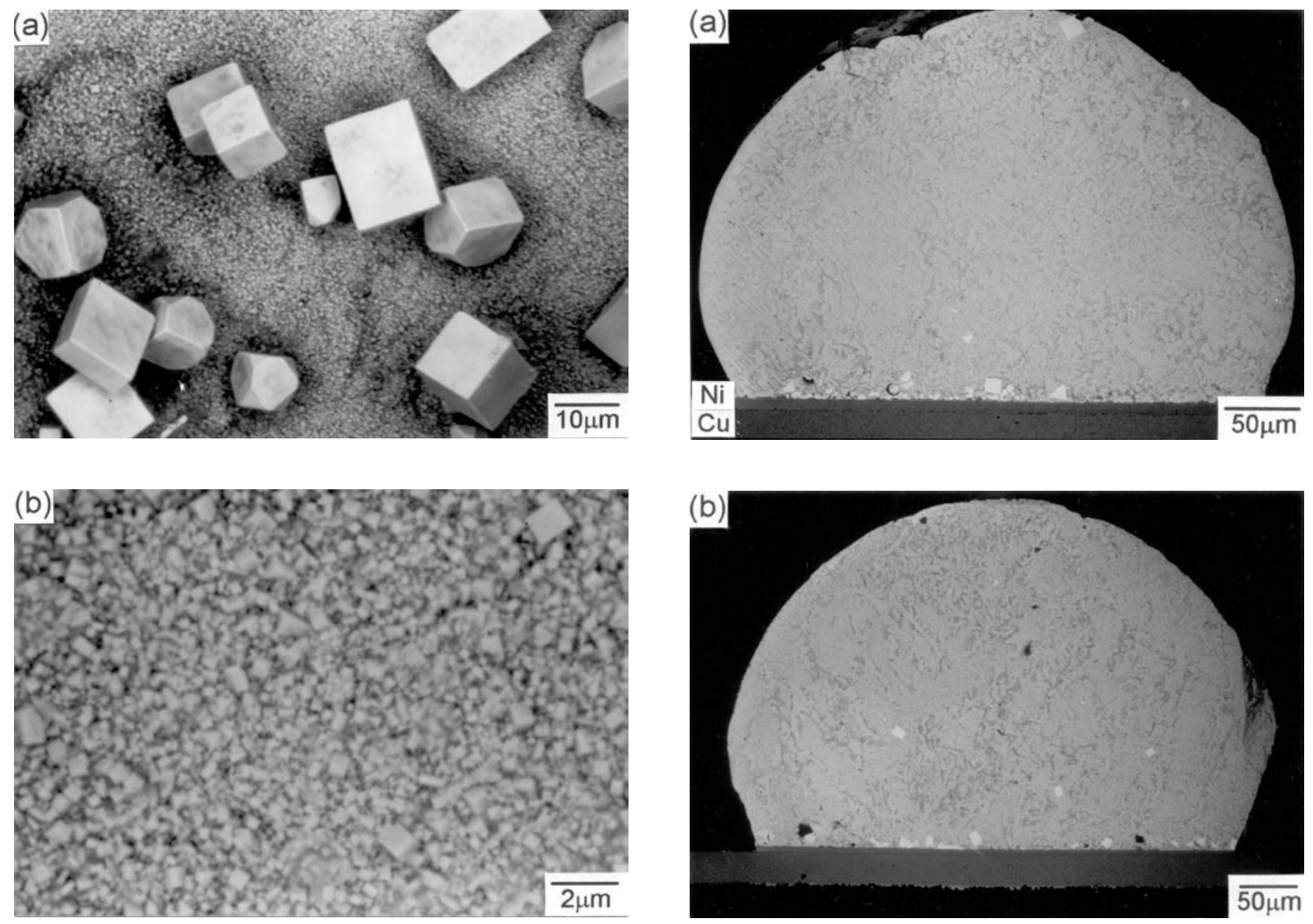

Fig. 8. (a) Selective etching of the In-49Sn solder showing that the cubic Auln $n_{2}$ interfacial intermetallic compounds are formed in BGA specimens after reflow at $220^{\circ} \mathrm{C}$ for $140 \mathrm{sec}$. (b) Magnified morpohology of the matrix in Fig. 8 a.

acteristics after ball shear testing (Fig. 10). Fracture occurs to all the solder joints as cracks propagate through the In-49Sn solder balls. The fracture behavior of such BGA In-49Sn is affected by neither the continuous intermetallic layer formed below $170^{\circ} \mathrm{C}$ nor the cubic-shaped $\mathrm{AuIn}_{2}$ formed above $200^{\circ} \mathrm{C}$. Independent of various reflow conditions, the ball shear strengths of all In-49Sn BGA packages used in this study are in the vicinity of $3 \mathrm{~N}$, as listed in Table I.

\section{CONCLUSIONS}

During the reflow of In-49Sn BGA packages, interfacial reactions occur between the liquid In-49Sn solder balls and $\mathrm{Au} / \mathrm{Ni} / \mathrm{Cu}$ pads. As the experimental results indicate, there are two types of intermetallic compounds formed after reflow under various reflow conditions. At peak temperatures below $170^{\circ} \mathrm{C}$, a continuous bilayered $\mathrm{Au}(\mathrm{In}, \mathrm{Ni})_{2} / \mathrm{Au}(\mathrm{In}, \mathrm{Ni})$ intermetallic appears at the interface. However, a cubic-shaped $\mathrm{AuIn}_{2}$ intermetallic can be observed at peak temperatures above $200^{\circ} \mathrm{C}$. By selectively etching the In-49Sn solder balls, the remaining

Fig. 9. Migration of Auln $\mathrm{n}_{2}$ cubes toward the upper domes of In-49Sn solder balls after reflow at high peak temperatures: (a) $200^{\circ} \mathrm{C}$, $160 \mathrm{sec},(\mathrm{b}) 220^{\circ} \mathrm{C}, 140 \mathrm{sec}$.

intermetallic compounds formed at the early stage at $170^{\circ} \mathrm{C}$ show a composition of $\mathrm{Au}_{87.6} \mathrm{In}_{10.4} \mathrm{Sn}_{2.0}$, which are later transformed into the double layer $\mathrm{Au}(\mathrm{In}, \mathrm{Ni})_{2} / \mathrm{Au}(\mathrm{In}, \mathrm{Ni})$ phases. Underneath the granular $\mathrm{Au}(\mathrm{In}, \mathrm{Ni})_{2} / \mathrm{Au}(\mathrm{In}, \mathrm{Ni})$ intermetallics, there also exists an $\mathrm{Ni}_{3}(\mathrm{In}, \mathrm{Sn})$ phase. Through selective etching of the specimens, the cubic-shaped $\mathrm{AuIn}_{2}$ intermetallics formed at $200^{\circ} \mathrm{C}$ are shown to grow in a fine-grained $\mathrm{Ni}_{3}(\mathrm{In}, \mathrm{Sn})_{4}$ matrix. The $\mathrm{AuIn}_{2}$ cubes are observed to float toward the top of the In-49Sn solder ball, which might be attributed to the thermomigration phenomenon resulting from the temperature gradient between the top and bottom of the solder ball. Ball shear tests on these BGA specimens indicate that the strengths of In-49Sn solder joint are unaffected by morphological differences in the intermetallic compounds formed under various reflow conditions.

\section{ACKNOWLEDGEMENTS}

We thank the National Science Council (NSC) in Taiwan for sponsoring this research project under Grant No. 90-2216-E002-032. 

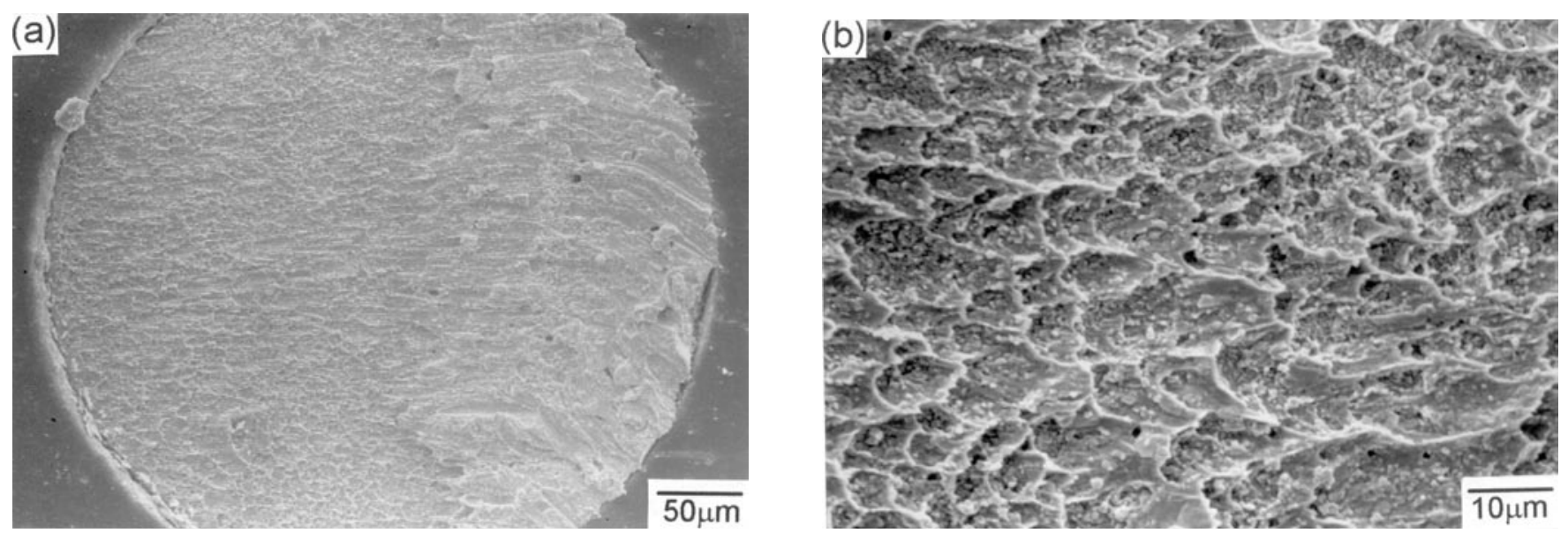

Fig. 10. Typical fractography of In-49Sn solder joints of the BGA packages used in this study after ball shear tests.

Table I. Ball Shear Strengths (Newtons) of the In-49Sn Solder Ball-Grid Array Packages in This Study after Reflow at Various Peak Temperatures for Various Melting Time Periods

\begin{tabular}{|c|c|c|c|c|c|c|c|}
\hline \multirow{2}{*}{$\begin{array}{l}\text { Peak } \\
\text { Temperature* }\left({ }^{\circ} \mathbf{C}\right)\end{array}$} & \multicolumn{7}{|c|}{ Melting Time Periods** (sec) } \\
\hline & 45 & 60 & 70 & 100 & 120 & 140 & 170 \\
\hline 140 & 2.55 & 2.86 & 2.97 & 2.85 & 3.12 & - & - \\
\hline 150 & - & 2.73 & 2.84 & 2.94 & 2.96 & 3.20 & - \\
\hline 160 & - & 2.53 & 2.97 & 3.00 & 2.94 & 2.98 & - \\
\hline 170 & - & 2.74 & 3.30 & 3.22 & 3.10 & 3.19 & - \\
\hline 200 & - & - & - & - & - & 3.01 & 3.02 \\
\hline 220 & - & - & - & 2.79 & 2.79 & 2.66 & 2.89 \\
\hline
\end{tabular}

* Peak temperature: The maximum temperatures on the reflow temperature profiles.

** Melting time periods: The time periods in which the reflow temperatures are above the melting point of In- $49 \mathrm{Sn}$ solder $\left(120^{\circ} \mathrm{C}\right)$.

\section{REFERENCES}

1. D.M. Jacobson and G. Humpston, Gold Bull. 22, 9 (1989).

2. N.C. Lee, Solid Surf. Mount Technol. 26, 65 (1997).

3. I. Shohji, S. Fujiwara, S. Kiyono, and K.F. Kobayashi, Scripta Mater. 40, 815 (1999).

4. F.G. Yost, F.P.G. Anyard, and M.M. Karnowsky, Metall. Trans. A 7A, 1141 (1976).

5. Z. Mei and J.W. Morris, J. Electron. Mater. 21, 599 (1992).

6. S.K. Kang and A.K. Saarkhel, J. Electron. Mater. 23, 701 (1994).

7. J. Glazer, Int. Mater. Rev. 40, 65 (1995).

8. K. Shimizu, T. Nakauishi, K. Karasawa, K. Hashimoto, and K. NiWa, J. Electron. Mater. 25, 39 (1996).
9. Z. Mei and J. Morris, J. Electron. Mater. 21, 401 (1992).

10. E. Zintl, A. Harder, and W. Haucke, Z. Phys. Chem. B 35, 354 (1937).

11. S.K. Kang and V. Ramachandran, Scripta Metall. 14, 421 (1980).

12. Y.H. Lin, Y.L. Chen, and T.H. Chuang, J. Electron. Mater. 29, 1047 (2000).

13. Y.H. Tseng (Ph.D. thesis, National Taiwan University, 2000).

14. S. Bader, W. Gust, and H. Hieber, Acta Metall. Mater. 43, 329 (1995).

15. G.J. Van Gurp, P.J. de Waard, and F.J. du Chatenier, J. Appl. Phys. 58, 728 (1985).

16. T.Y. Tan, Appl. Phys. Lett . 73, 2678 (1998). 